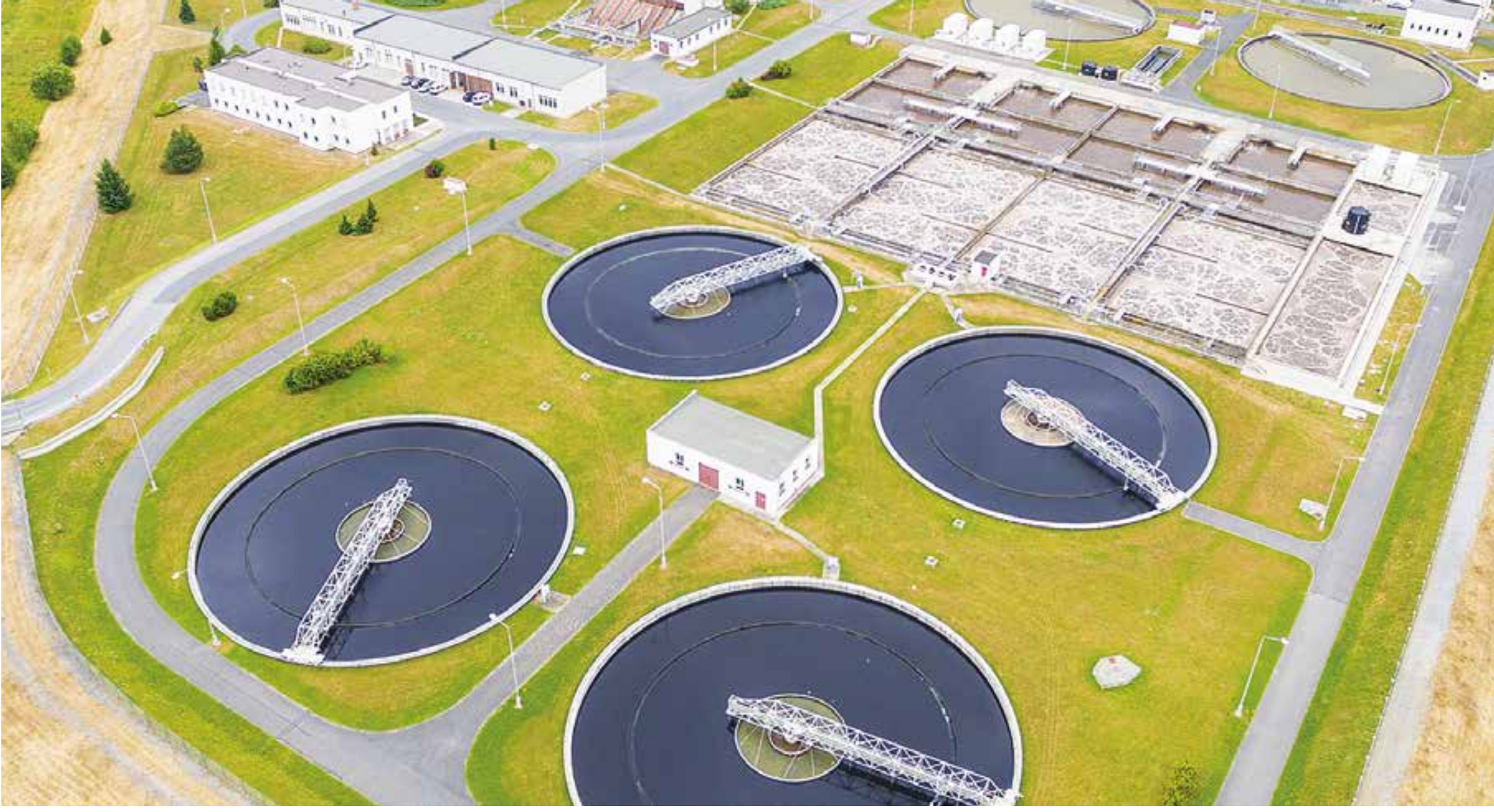

\title{
Odpadní voda - odpad nebo poklad?
}

\section{MARTINA BERÁNKOVÁ}

Klíčová slova: DESAR - separační toalety - dělení odpadních vod

\section{SOUHRN}

V současné době klimatických změn a uvědomělejšího chování k přírodě se mění prístup i k odpadním vodám. Dríve byly vnímány jen jako odpad, dnes se na ně díváme i jako na surovinu. A jiným přistupem k hospodaření s vodou můžeme i výrazně snížit spotřebu kvalitní vody, které není všude dostatek.

\section{ÚVOD}

Na otázku v názvu by odpověd’ mohla znít: Jak pro koho, jak kdy. Dřive jsme se otázkou zneškodňování odpadních vod moc nezabývali. Byla nastavena nějaká pravidla, voda byla laciná, technologie čištění odpadních vod se rozvíjely, a tak se jen zdokonaloval nastavený systém. Dnes, kdy je voda dražší, celosvětově pitné vody pravděpodobně ubývá, zdroje minerálních hnojiv se zmenšují a je strach z nedostatku ropy, se stále více lidí zamýšlí nad udržitelným způsobem žití, tedy i nad tím, jak se postavit jinak k odpadním vodám.

Po letošním suchém létě je i $v$ našich podmínkách na místě přemýšlet o úsporách vody a o jejím možném znovuvyužití.

\section{VÝZVY EVROPSKÉ UNIE}

V roce 2008 príijal Evropský parlament usnesení o řešení problému nedostatku vody a sucha v Evropské unii (2008/2074 (INI)), ve kterém doporučuje, aby EU zaujala při řešení nedostatku vody ucelený prístup, který bude kombinovat opatření k řízení poptávky po vodě, opatření k optimalizaci existujících zdrojů $\checkmark$ rámci koloběhu vody a opatření k vytváření nových zdrojů. Evropský parlament vyzývá k úsporám a hospodárnějšímu využívání vody.

Během několika posledních desítek let byl přístup k "běžné sanitaci“ několikrát kritizován, což mělo za následek navržení dalších definicí pro alternativní „udržitelnou sanitaci“ [1, 2].

Také oběhové hospodářství se stává jednou z hlavních priorit Evropské komise.

Česká republika podporuje posilování principů oběhového hospodářství. Kromě dalšího považuje za důležité, aby návrh legislativy týkající se oběhového hospodářství podpořil bezpečné a nákladově efektivní opětovné využívání vody a přispěl ke stanovení pravidel pro využívání vyčištěných odpadních vod jako druhotné suroviny [3]. 


\section{ZACHÁZENÍ S ODPADNÍMI VODAMI}

Obecně Ize říci, že řešení zneškodňování odpadních vod má dvě hlavní varianty. Centralizované a decentralizované. To, že ani jeden systém nepřeválcuje ten druhý, je již jasné. Za př́klad může posloužit Německo, kde velkolepé plány o tom, že všechny komunální vody budou čištěny centrálně, byly nahrazeny stř́izlivými pragmatickými řešeními, které vycházejí z ekonomických kalkulací pro jednotlivé varianty. Decentralizované zneškodňování odpadních vod se stává alternativou centralizovaného čištění, které v mnoha př́padech není optimální variantou nejen z ekologického, ale ani ekonomického pohledu [4].

Pro vyjádření pojmu decentralizované odvádění a opětovné využití odpadních vod se v zahraničí používá akronym DESAR (decentralised sanitation and reuse). Jde o decentralizované řešení nakládání s odpadními vodami v jednotlivých domech. Princip je založený na separaci znečištění u zdroje, na odděleném čištění odpadních vod, jejich opětovném použití a na efektivním hospodaření s deštovou vodou. Jednotlivé DESAR koncepty nabízejí různé varianty dělení odpadních vod z domácností a jejich znovupoužití. Tyto systémy udržují jednotlivé druhy odpadních vod blízko místa vzniku, a tak umožňují zkrácení a uzavření vodního cyklu v domácnostech, a tím úspory pitné vody i financí. Existuji i projekty na využití tepelné energie z odpadních vod.

Základní myšlenkou je netradiční zacházení a nakládání s odpadní vodou jako s cennou surovinou, kterou lze využít a zpracovat v místě jejího vzniku [4-6].

Nově se začíná používat také zkratka NASS pro nové způsoby sanitace. Firma ASIO tuto zkratku vysvětluje jako nekonvenčně aranžované sanitární systémy. Použitím NASS mohou být sledovány různé cíle, k nimž patří redukce spotřeby vody, zpracování odpadů, dělení vod a také možnost přizpůsobení řešení odpadních vod místním podmínkám. Koncepce umožňují například využití zdrojů, které se v odpadních vodách vyskytují. Na místě se dá napríklad kal využít jako hnojivo v zemědělství, šedé vody na zálivku nebo jako užitková voda v domácnosti. Použití NASS již bylo odzkoušeno na některých sídlištích v rámci pilotních projektů a ukázalo se jako smysluplné (např. ekologické sídliště Bielefeld-Waldquelle, ekologické síldiště s kompostovacími toaletami Allermöhe, Hamburk). Charakteristickým rysem pro použití NASS je individuální řešení pro každou lokalitu [4].

Myšlenky dělení a využivání jednotlivých druhů odpadních vod se objevily již $\vee$ minulosti. Separace moči (žlutých vod) byla v Evropě zavedena v 70. a 80. letech minulého století ve Švédsku, kde byly v prázdninových domech se suchými toaletami osazovány kompostovací komponenty s oddělováním moči. V letech 1996 až 1999 byl následně vyvijjen a ve školách instalován separační systém na principu dělicích (no-mix) toalet a suchých pisoárů - tedy pisoárů bez použití vody (waterless). Od roku 2000 se tato země díky predchozím studiím a výzkumům stala mezinárodně uznávanou v oblasti výzkumu, návrhu a výroby separačních zařízení [7].

Tabulka 1. Zastoupení hlavních živin v jednotlivých druzích vod

Table 1. Representation of the nutrients in various kinds of waters

\begin{tabular}{lcccc}
\hline Prvky & $\begin{array}{c}\text { Produkce } \\
{[\mathbf{k g . ( o b y v .}} \\
\left.\text { rok) }{ }^{-1}\right]\end{array}$ & $\begin{array}{c}\text { Šedé } \\
\text { vody }\end{array}$ & $\begin{array}{c}\text { Žluté } \\
\text { vody } \\
\text { (moč) }\end{array}$ & $\begin{array}{c}\text { Hnědé } \\
\text { vody } \\
\text { (fekálie) }\end{array}$ \\
\hline $\mathrm{N}$ & $3,2-5$ & $3-8 \%$ & $80-87 \%$ & $7-13 \%$ \\
\hline $\mathrm{P}$ & $0,48-0,75$ & $10-28 \%$ & $35-55 \%$ & $25-40 \%$ \\
\hline $\mathrm{K}$ & $0,33-1,8$ & $13-34 \%$ & $54-60 \%$ & $12-27 \%$ \\
\hline
\end{tabular}

Tabulka 2. Průmérná denní spotřeba vody Table 2. Average daily water consumption

\begin{tabular}{lc} 
Použití & Spotřeba (I) \\
\hline WC & 25 \\
\hline Osobní hygiena & 40 \\
\hline Praní, úklid & 16 \\
\hline Př́írava jídla, mytí nádobí & 8 \\
\hline Mytí rukou & 6 \\
\hline Zalévání & 5 \\
\hline Pití & 2 \\
\hline Ostatní & 4 \\
\hline CELKEM & 106 \\
\hline
\end{tabular}

Odpadní vody jsou děleny na vody černé (voda z toalet, tedy moč, fekálie, toaletní papír a splachovací voda) a šedé (ostatní voda z domácnosti, tedy voda z kuchyně - dřez, myčka, voda ze sprch, umyvadel a praček). Černé vody se dále dělí na vody žluté (moč) a hnědé (fekálie) $[4,5]$.

\section{Žluté vody}

Žlutá voda, tedy moč, se skládá z vodného roztoku metabolických odpadů, hlavně močoviny, rozpuštěných solí, zejména chloridu sodného, a dalších organických látek. Obsahuje nutrienty, jedná se zejména o dusík (N), fosfor (P) a draslík (K), dále síru, bór a další prvky. Jejich skutečný obsah se liší v závislosti na stravě. Moč je obvykle dobře vyvážené hnojivo s podobným poměrem hlavních živin jako průmyslově vyráběné hnojivo NPK. Pro hnojení se ji doporučuje ředit $\checkmark$ poměru 1: 8 s vodou. Jeden člověk vyprodukuje ročně přibližně 500 I moči.

\section{Hnědé vody}

Hnědými vodami se rozumějí fekálie, které obsahují především uhlík, méně dusík, fosfor a draslík, ale také větší množství vápníku, hořčíku a železa. Jeden člověk vyprodukuje ročně kolem 50 I fekálií.

\section{Černé vody}

Klasickým odváděním odpadních vod z toalet - tzn. hnědých a žlutých vod současně - získáváme vody černé. Pokud dokážeme černé vody zadržovat oddělené od ostatních (budou tedy velice málo zreděné), můžeme je přeměnit na prírodní hnojivo, kterým budeme umět nahradit syntetické produkty. $\checkmark$ některých pilotních projektech bylo použito separování výhradně černých vod (využití v zemědělství ke hnojení). 


\section{Šedé vody}

Šedou vodou nazýváme podle normy EN 12056 (Vnitřní kanalizace) splaškové odpadní vody neobsahující fekálie a moč, které odtékají z umyvadel, van, sprch, dřezů apod. Šedou vodu, zejména z koupelen, je možné po úpravě využívat jako vodu provozní (tzv. bílou vodu) pro splachování záchodů, pisoáru a zalévání zahrad. Nejvýznamnější znečištění šedých vod zpưsobují detergenty z pracích prášků, šamponů, mýdel, zubních past a podobně. Odpadní vody z kuchyňských umyvadel a z drtičů odpadů jsou občas vyjímány ze zdrojů šedé vody, protože mívají vysokou koncentraci znečištění. V tabulce 1 je uvedeno zastoupení hlavních živin v jednotlivých druzích odpadních vod [5,8].

Koncept separace pomocí separačních zařizení zabezpečuje oddělené nakládání a čištění různých druhů odpadních vod zvlášť. Jako separační zařízení se používají kompostovací toalety nebo separační toalety (no-mix toalety, pisoáry). Separační toalety slouží k separaci žlutých a hnědých vod. Jejich používání je stejné jako u klasických toalet. Všechny se skládají ze dvou oddělených mušlí, často se používá separační vložka do toalety. Moč je shromažd’ována v přední části konstrukce, odkud je dopravována do sběrného akumulačního tanku, fekálie v zadní části. Moč z akumulačního tanku je možno po naředění 1 : 8 použít na hnojení. Fekálie se doporučuje skladovat v zásobníku půl roku a pak je zkompostovat. Separační toalety mají zpravidla dva zásobníky na výměnu.

Kompostovací toalety mají zásobník, ve kterém se shromaždují moč a fekálie společně, zároveň zde probíhá kompostování. Za tím účelem je do zásobníku obvykle přidáván popel, piliny nebo jiný materiál, aby se usnadnilo kompostování. Obecně mají kompostovací toalety menší kapacitu než toalety separační [9].

Každá osoba, která má přístup ke zdroji vody z veřejného vodovodu, vyprodukuje ročně odpadní vodu v rozmezí 20000 až 100000 I [2]. Podle údajů vodohospodářské společnosti Pražské vodovody a kanalizace byla průměrná denní spotřeba vody v Praze v roce 2014 na osobu 106 litrů, tedy $39 \mathrm{~m}^{3}$ za rok ( $v$ ostatních regionech ČR je spotřeba vody na osobu a den nižší). Cena vody v roce 2015 byla pro Pražany 77,65 Kč za 1000 I vody. Nejvíce utratí za vodu použitou na osobní hygienu (přes 3 Kč za den), hned pak za používání splachovacích toalet (skoro 2 Kč za den) [10]. V tabulce 2 je uvedena denní spotřeba vody podle údajů Pražských vodovodů a kanalizací.

\section{LEGISLATIVA}

Co se týká legislativy, není u nás nakládání s oddělenými odpadními vodami řešeno. Proto je výklad úředníků různý. Někdo považuje moč za odpadní vodu, někdo za hnojivo. Pokud by byla žlutá voda posuzována podle zákona č. 254/2001 Sb. § 38 odst. 1, o vodách, byla by směs moči a vody brána jako odpadní voda. Pokud by Státní zdravotní ústav vydal pozitivní stanovisko k posouzení uskladněné žluté vody jako hnojiva, musela by se následně provést registrace žlutých vod jako hnojiva v souladu se zákonem č. 156/1998 Sb., o hnojivech. Podle některých není možno podle zákona o odpadech a zákona o hnojivech lidské výkaly kompostovat. Nabízí se ale i výklad, že výkaly ze suchých a kompostovacích toalet by teoreticky mohly spadat v katalogu odpadů do kolonky "kal ze septiků a žump", a ty se kompostovat smějí, pokud splní mikrobiologické ukazatele podle vyhlášky č. 341/2008 Sb., o podrobnostech nakládání s biologicky rozložitelnými odpady.

Od řijna 2015 platí infringementová novela, kterou se mění zákon č. 185/2001 Sb., o odpadech a o změně některých dalších zákonů. Pưvodní zákon o odpadech se nevztahoval na odpadní vody, novela se nevztahuje jen na odpadní vody, které podléhají zákonu o vodách a zákonu o vodovodech a kanalizacích. To dává větší prostor zákonu o odpadech, který se bude týkat i odpadních vod mimo působnost výše zmíněných dvou zákonů. Kromě této změny se ohledně odpadních vod v novele zákona nic němění. Zatím není jasné, jak se v praxi tato úprava bude projevovat.
Při využívání jednotlivých druhů vod existuje samozřejmě i hygienické riziko, které ale není u řešení v jednotlivých domácnostech velké. Jde vždy o individuální řešení, ve kterém nesmí chybět hledisko hygieny a bezpečnosti.

Začněme tedy rozumně šetřit se zdroji Země. Bude lépe nám i naší planetě.

\section{Literatura}

[1] TREML, P. Monitoring a plánování v období nedostatku vody a sucha z pohledu Evropské unie, VTEI, Č. 3, 2013, s. 6-12.

[2] BODÍK, I. a RIDDERSTOLPE, P. Udržitelná sanitace v zemích střední a východní Evropy, Tisk GWP, 2007.

[3] Rámcová pozice ke Sdělení Komise Evropskému parlamentu, Radě, Evropskému hospodářskému a sociálnímu výboru a Výboru regionů - Uzavření cyklu - Akční plán EU pro oběhové hospodářství. [4] Články firmy ASIO. Dostupné z: www.asio.cz.

[5] SKLENÁROVÁ, T. Decentralizovaný způsob nakládání s odpadními vodami. TZB Haustechnik, č. 1, 2009, s. 26-29.

[6] BARTONÍK, A. a PLOTĚNÝ, K. Recyklace tepla v budovách - šedé vody. Sborník semináře Energie zodpadnich vod. Brno: ASIO, 2011, s. 17-20.

[7] JOHANNSON, M. Source-Separated Human Urine - A Future Source of Fertilizer for Agriculture in the Stockholm Region. Final report of the R\&D project "Source-Separated Human Urine - a Future Source of Fertilizer for Agriculture in the Stockholm Region". 2001.

[8] ŠÁLEK, J. a kol. Voda v domè a na chatě, Grada 2012. ISBN 978-80-247-3994-6.

[9] Návody kseparačním a kompostovacím toaletám firmy ELIA. Dostupné z: www.elia.cz.

[10] Dostupné z: http://www.pvk.cz/vse-o-vode/pitna-voda/spotreba-vody/.

\section{Autor}

Ing. Martina Beránková

凶martina_berankova@vuv.cz

Výzkumný ústav vodhohospodářský T. G. Masaryka, v. v. i.

Přispěvek prošel lektorským řizením.

\section{WASTE WATER - WASTE OR TREASURE?}

\section{BERANKOVA, $M$.}

TGM Water Research Institute, p. r. i.

Keywords: DESAR - NoMix Toilet- alternative water systems

At the time of changing climatic conditions and reducing the quantity of raw material it is necessary to start saving water and raw materials. To achieve this target it is good to separate wastewater at the source and using of no-mix toilets. Czech legislation is not yet adapted to this alternative treatment of waste water. 